\title{
Refractometric determination of water content in royal jelly*
}

\author{
Giulio SESTA, Lorenzo LUSCO \\ C.R.A., Istituto Sperimentale per la Zoologia Agraria, Sezione di Apicoltura Via L. Rech 36, 00156 Rome, Italy
}

Received 13 April 2007 - Revised 29 September 2007 - Accepted 1 October 2007

\begin{abstract}
A correlation was found between the measured refraction index of royal jelly and its water content as determined by vacuum oven drying. Twenty-seven different royal jelly samples were analysed for their water content by performing 24 hour vacuum drying at $48{ }^{\circ} \mathrm{C}$, obtaining values that covered almost the entire range reported in literature. The refraction index values for the same samples were measured using a thermostated Abbe refractometer. A simple linear relationship $\left(\mathrm{R}^{2}=0.96\right)$ between refraction index and water content was found proving the fitness of a refractometric measure for quality control purposes. The relationship provides estimates of water content that are similar to those resulting from the Wedmore equation $\left(\mathrm{R}^{2}=0.9999\right)$ used to estimate water content in honey. The refractometric evaluation of the water content provides sufficient reliability for the routine quality control of royal jelly and is faster and simpler than currently used methods.
\end{abstract}

royal jelly / water / refractometer

\section{INTRODUCTION}

Royal jelly (RJ) is the hypopharyngeal gland secretion of young nurse bees used to feed young larvae and the queen bee and has a fundamental role in caste differentiation. The spectacular fertility and long life-span of the queen bee are responsible for the strong appeal of this product on consumers. RJ is marketed in various forms, raw (fresh), freeze dried and in preparations (Bloodworth et al., 1995). Most of the RJ marketed in Europe is imported from China, the world largest producer, but in the last years the interest of European beekeepers for the production of RJ increased. This brought researchers, producers, importers, private laboratories and control agencies to create a working group of the International Honey Commission (IHC, 2004) to define a standard that establishes a defini-

Corresponding author: G. Sesta, giulio.sesta@ apicoltura.org

* Manuscript editor: Jean-Noël Tasei tion of the product, parameters and analytical methods for quality control. In this scope, a new method for the determination of RJ sugars was developed (Sesta, 2006).

The composition of RJ was studied by several authors, but data available in the literature are affected by a considerable variety, partly because of the intrinsic variability of the product, partly because of the use of different analytical methods. According to several studies the water content of the product lies between 60 and $70 \mathrm{~g} / 100 \mathrm{~g}$ (Pourtallier et al., 1990; Lercker et al., 1992; Piana 1996). Besides water, the main components of RJ are sugars $(18-52 \%$ dry weight), proteins (17-45\% d.w), lipids (3.5-19\% d.w.) and minerals (2-3\% d.w) (Piana, 1996).

RJ water content is an important quality criterion and its determination is always a part of the quality control on raw RJ. Up to the present several methods have been used: Karl Fischer method (Serra Bonvehi, 1991, 1992; Garcia-Amoedo and Almeida-Muradian, 2002), desiccation by 
sulphuric acid (Garcia-Amoedo and AlmeidaMuradian, 2002) and different drying methods: freeze drying (Pourtallier et al., 1990; Lercker et al., 1992), oven and vacuum oven (Palma, 1992; Garcia-Amoedo and AlmeidaMuradian, 2002), infrared (Garcia-Amoedo and Almeida-Muradian, 2002). These methods were compared with each other and it was found that most of them yielded different values. Drying at $60{ }^{\circ} \mathrm{C}$ yielded the same values as the Karl Fischer method (Garcia-Amoedo and Almeida-Muradian, 2002), which is considered as the most precise method for humidity determination in food.

All these methods are time consuming or require specific equipment. An early Russian work reported on the relationship between humidity and refractive index in RJ (Braines and Gamov, 1962). However, as it is an institute report, inaccessible to the general public, its results (in the form of a humidity vs refractive index table) are reported in a Bulgarian book (Shkenderov and Ivanov, 1983). We conducted the present work to verify whether the simple refractive index measurement, already used for honey moisture determination (Wedmore, 1955; Bogdanov et al., 1997), also could be reliably used for routine control purposes for RJ.

\section{MATERIALS AND METHODS}

\subsection{RJ samples}

The study was carried out on $27 \mathrm{RJ}$ samples of different origin. Nine samples collected from April to September 2005 were provided by Italian producers, eight samples were imported from unknown countries and ten samples were produced by our Institute's beekeeping farm during 2005 Spring. All samples were kept refrigerated, in tightly sealed containers, at ca. $4{ }^{\circ} \mathrm{C}$ for no more than 18 months before measurement. Both a vacuum oven (VO) drying method and a refractive index (RI) measurement method were applied to the 27 samples.

\subsection{Oven drying method}

For determining the RJ water content a vacuum oven (VO) drying was chosen as the refer- ence method for comparison with the refractive index measurement method. Due to vacuum which accelerates water loss, the VO method can employ lower temperatures than simple oven drying. Consequently our drying method used $48^{\circ} \mathrm{C}$.

The VO method for determining the water content in RJ requires some care. To enable complete water loss, the sample has to be spread in a thin layer on a wide surface. However, in the weighing step, this causes a visible loss of water by evaporation, producing an unstable and continuously decreasing reading of the weight on the scale. To obtain an accurate measure of the processed RJ amount, the VO method was performed as follows:

- The oven (ISCO, model NSV 9035) and the vacuum pump (KNF, model N86KT 18) were turned on two hours before inserting the samples; the temperature was set at $48^{\circ} \mathrm{C}$, the vacuum reached was higher than -800 mbar, resulting in a pressure lower than 200 mbar.

- The Petri dish where the sample was to be spread was weighed on the analytical scale (Mettler-Toledo, precision $0.1 \mathrm{mg}$ ) and its weight was recorded as "Petri".

- The clean spatula to be used for spreading the sample was weighed on the analytical scale (and its weight was recorded as "clean spatula").

- A homogenized RJ sample aliquot of approximately $3 \mathrm{~g}$ (technical scale) was transferred to the Petri dish as fast as possible and immediately weighed at the analytical scale (recorded as "Petri + RJ").

- Using the weighed spatula the RJ was carefully spread uniformly over the dish surface, then the spatula, on which some residue of RJ remained, was weighed again and its weight recorded as "dirty spatula" (to take into account the small amount of sample left on the spreading tool). The accurate amount of RJ sample processed was calculated as:

$$
\begin{gathered}
\text { ("Petri + RJ" - "Petri") - ( "dirty spatula" - } \\
\text { "clean spatula") }
\end{gathered}
$$

- The Petri dish was then transferred to the VO and kept there for 24 hours.

- After that time the dried sample was transferred into a desiccator, kept there for fifteen minutes to reach ambient temperature and then weighed in the analytical balance.

The repeatability of the VO method was evaluated performing six determinations on the same RJ sample. 


\subsection{Refractive index method}

The measurement of the RI for the RJ samples was performed using an Abbe refractometer (ATAGO, model 3T) connected to a thermostated water bath (Frigiterm, P Selecta) that kept the temperature constant at $20^{\circ} \mathrm{C}$. The sample was kept in a refrigerator up to thirty minutes before analysis and then left to equilibrate at ambient temperature. The RI was measured on an aliquot of a carefully homogenized sample, without any other preliminary treatment. The sample was left in the refractometer to equilibrate thermally for two minutes and then the reading was performed. The refractometer was then cleaned and dried before the measure of the next sample.

The repeatability of the RI determination was evaluated performing 10 subsequent measures under repeatability conditions on the same RJ samples used for testing the repeatability of the VO method.

\subsection{Statistics}

The repeatability tests for the RI measurement and for the VO water content determination were performed to evaluate their repeatability, intended as "closeness of the agreement between the results of successive measurements of the same measurand (quantity intended to be measured) carried out under the same conditions of measurement" (ISO V.I.M., 1993). Replicate measurements or determinations were thus performed under "repeatability conditions" that include: the same measurement procedure, the same observer, the same measuring instrument, used under the same conditions, the same location, repetition over a short period of time (ISO V.I.M., 1993). As repeatability may be expressed quantitatively in terms of the dispersion characteristics of the results (ISO V.I.M., 1993) it was expressed in the form of an expanded uncertainty on the result at a $95 \%$ confidence level. The expanded uncertainty is used to provide an interval which may be expected to encompass a large fraction of the distribution of values which could reasonably be attributed to the measurand (UNI CEI ENV 13005, 2000). From the repeatability tests an experimental standard deviation $\mathrm{s}_{r}$ was obtained and this value can be considered (EURACHEM/CITAC, 2000) an estimate of the standard repeatability uncertainty (the component of the uncertainty on the determined value due to the repeatability of the measure, expressed as a standard deviation). To obtain the expanded repeatability uncertainty at a $95 \%$ confidence level $\mathrm{U}_{r, 95 \%}$ we have to multiply the $\mathrm{s}_{r}$ by the coverage factor $\mathrm{k}_{95 \%, v=n-1}$ relative to $\mathrm{n}-1$ degrees of freedom $\left(\mathrm{U}_{r, 95 \%}=\mathrm{k}_{95 \%, v=n-1} \cdot \mathrm{s}_{r}\right)$. The coverage factor $\mathrm{k}$ is the two-tailed value of Student's $t$ for the number of degrees of freedom associated with the study replicates, and for the $95 \%$ confidence level.

\section{RESULTS}

\subsection{RI repeatability}

The results of the repeatability test for the refractive index measurement are shown in Table I. The standard deviation determined for a ten replicate set of RI measurements performed under repeatability conditions was $\mathrm{s}_{r}(\mathrm{RI})=0.00013$ RIU (refractive index units). This value can be considered an estimate of the standard repeatability uncertainty. To obtain the expanded repeatability uncertainty at a $95 \%$ confidence level $\mathrm{U}_{r, 95 \%}(\mathrm{RI})$ we have to multiply the $\mathrm{s}_{r}(\mathrm{RI})$ by the coverage factor relative to nine degrees of freedom $\left(\mathrm{k}_{95 \%, v=n-1}=2.262\right)$, thus obtaining $\mathrm{U}_{r, 95 \%}(\mathrm{RI})=\mathrm{k}_{(95 \%, v=n-1)} \cdot \mathrm{s}_{r}(\mathrm{RI})=$ 0.0003 RIU.

\section{2. $\mathrm{W}_{\text {vo }}$ repeatability}

The results of the repeatability test for the vacuum oven method are also shown in table I. For the water content results obtained by the VO method ( $\left.\mathrm{W}_{\mathrm{VO}}\right)$ we calculated the expanded repeatability uncertainty at a $95 \%$ confidence level $\mathrm{U}_{r, 95 \%}\left(\mathrm{~W}_{\mathrm{VO}}\right)=0.28 \mathrm{~g} / 100 \mathrm{~g}$ RJ. The $48{ }^{\circ} \mathrm{C}$ temperature used for the VO method resulted in no brown superficial crust, which prevents complete evaporation of water at higher temperatures. After the 24 hour drying period the colour of the RJ sample remained unchanged while the consistency had become vitreous.

\subsection{Analysis of the samples, $\mathrm{W}_{\mathrm{VO}}-\mathrm{RI}$ relationship}

After performing the repeatability tests the two methods were applied to the analysis of 
Table I. Precision parameters obtained from the repeatability tests performed for the vacuum oven determination $(\%=\mathrm{g} / 100 \mathrm{~g} \mathrm{RJ}$, fresh weight) of water content and for the refractive index measurement (RIU = refractive index units).

\begin{tabular}{lcc}
\hline & Vacuum oven determination & Refractive index measurement \\
\hline No. repetitions $(\mathrm{n})$ & 6 & 10 \\
Average value & $60.3 \%$ & $1.3948 \mathrm{RIU}$ \\
Standard deviation $\left(\mathrm{s}_{\mathrm{r}}\right)$ & $0.11 \%$ & $0.00013 \mathrm{RIU}$ \\
$\mathrm{k}_{(95 \%, v=n-1)}$ & 2.571 & 2.262 \\
$\mathrm{U}_{r, 95 \%\left(=\mathrm{k}_{(95 \%, v=n-1)} \cdot \mathrm{s}_{r}\right)}$ & $0.28 \%$ & $0.0003 \mathrm{RIU}$ \\
\hline
\end{tabular}

the 27 RJ samples. The results of the RI measurements and of the water content determinations by VO drying are reported in the first two columns of Table II. The $\mathrm{W}_{\mathrm{VO}}$ measures of the $27 \mathrm{RJ}$ samples were linearly correlated to the correspondent RI measures (Fig. 1). The resulting linear relationship (a) presents a significant linear correlation coefficient $\left(\mathrm{R}^{2}=\right.$ 0.9605) and enables estimation of the RJ water content from RI measurements $\left(\mathrm{W}_{\mathrm{RI}}\right)$ via the following equation (a):

$$
\mathrm{W}_{\mathrm{RI}}(\%)=-492.9 \times \mathrm{RI}+747.9
$$

\subsection{Water content determination and uncertainty estimation}

For honey, the water content is calculated from the RI measure by applying the equation of Wedmore (1955):

$\mathrm{W}_{\text {Wed }}(\%)=[-0.2681-\log (\mathrm{RI}-1)] / 0.002243$.

For each of the 27 RJ samples the water content $\mathrm{W}_{\mathrm{RI}}$ predicted by the experimental equation (a) and the water content $\mathrm{W}_{\text {Wed }}$ predicted by the Wedmore equation (b) were calculated from the measured RI and reported in the last two columns of Table II.

There was a strong correlation between $\mathrm{W}_{\text {Wed values and }} \mathrm{W}_{\mathrm{RI}}$ values $\left(\mathrm{R}^{2}=0.9999\right)$.

The Wedmore equation (b) is therefore suitable for the determination of the water content of RJ.

To roughly evaluate the uncertainty on the water content estimated by applying the Wedmore equation on the RI measurements, the 27 predicted $\mathrm{W}_{\text {wed }}$ values were compared with the experimentally determined $W_{\text {VO }}$ values
Table II. Water content $(\%=g / 100$ RJ, fresh weight) through the vacuum oven method $\left(\mathrm{W}_{\mathrm{VO}}\right)$ in $27 \mathrm{RJ}$ samples and corresponding RI values. Water content are calculated by using the RI values and applying either equation (a) $\left(\mathrm{W}_{\mathrm{RI}}\right)$ or the Wedmore equation (b) $\left(\mathrm{W}_{\mathrm{Wed}}\right)$. Equation (a): refer to Figure 1. Wedmore equation (b): $\mathrm{W}_{\mathrm{Wed}}(\%)=[-0.2681-$ $\log (\mathrm{RI}-1)] / 0.002243$.

\begin{tabular}{|c|c|c|c|c|}
\hline Sample & $\mathrm{W}_{\mathrm{VO}} \%$ & $\begin{array}{c}\mathrm{RI} @ 20^{\circ} \mathrm{C} \\
\text { (RIU) }\end{array}$ & $\mathrm{W}_{\mathrm{RI}} \%$ & $\mathrm{~W}_{\text {Wed }} \%$ \\
\hline 1 & 60.3 & 1.3948 & 60.3 & 60.4 \\
\hline 2 & 60.7 & 1.3950 & 60.2 & 60.3 \\
\hline 3 & 62.4 & 1.3908 & 62.3 & 62.4 \\
\hline 4 & 60.8 & 1.3926 & 61.4 & 61.5 \\
\hline 5 & 61.8 & 1.3928 & 61.3 & 61.4 \\
\hline 6 & 60.8 & 1.3946 & 60.4 & 60.5 \\
\hline 7 & 53.8 & 1.4084 & 53.6 & 53.9 \\
\hline 8 & 62.4 & 1.3898 & 62.8 & 62.9 \\
\hline 9 & 62.7 & 1.3883 & 63.6 & 63.6 \\
\hline 10 & 63.2 & 1.3872 & 64.1 & 64.2 \\
\hline 11 & 60.7 & 1.3920 & 61.7 & 61.8 \\
\hline 12 & 60.3 & 1.3938 & 60.8 & 60.9 \\
\hline 13 & 62.1 & 1.3903 & 62.6 & 62.6 \\
\hline 14 & 63.6 & 1.3882 & 63.6 & 63.7 \\
\hline 15 & 59.0 & 1.3966 & 59.5 & 59.5 \\
\hline 16 & 59.6 & 1.3972 & 59.2 & 59.2 \\
\hline 17 & 61.0 & 1.3944 & 60.5 & 60.6 \\
\hline 18 & 63.4 & 1.3894 & 63.0 & 63.1 \\
\hline 19 & 63.6 & 1.3882 & 63.6 & 63.7 \\
\hline 20 & 64.2 & 1.3878 & 63.8 & 63.9 \\
\hline 21 & 63.8 & 1.3892 & 63.1 & 63.2 \\
\hline 22 & 64.7 & 1.3856 & 64.9 & 65.0 \\
\hline 23 & 64.9 & 1.3860 & 64.7 & 64.8 \\
\hline 24 & 65.7 & 1.3858 & 64.8 & 64.9 \\
\hline 25 & 64.7 & 1.3858 & 64.8 & 64.9 \\
\hline 26 & 64.8 & 1.3856 & 64.9 & 65.0 \\
\hline 27 & 66.6 & 1.3833 & 66.0 & 66.1 \\
\hline Min & 53.8 & 1.3833 & 53.6 & 53.9 \\
\hline Max & 66.6 & 1.4084 & 66.0 & 66.1 \\
\hline
\end{tabular}




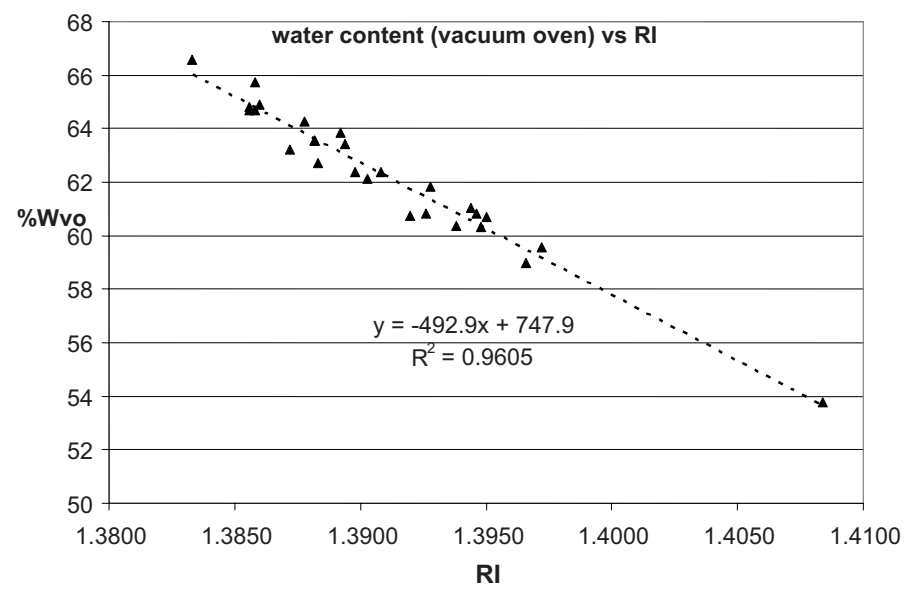

Figure 1. Relationship between water content values determined by the vacuum oven method $\left(\mathrm{W}_{\mathrm{vo}}\right)$ and RI values, estimated on 27 RJ samples.

which were characterized by a low repeatability uncertainty. By plotting the $\mathrm{W}_{\text {Wed }}$ against the $\mathrm{W}_{\mathrm{VO}}$ and considering negligible the uncertainty on the $\mathrm{W}_{\mathrm{VO}}$, we estimated the standard uncertainty on the $\mathrm{W}_{\text {Wed }}$ from the residuals of the fit with a simple formula:

$$
\begin{aligned}
\mathrm{u}\left(\mathrm{W}_{\mathrm{Wed}}\right) & =\left[\left(\sum_{i}\left(\mathrm{~W}_{\mathrm{Wed}, \mathrm{i}}-\mathrm{W}_{\mathrm{VO}, \mathrm{i}}\right)^{2}\right) /(n-2)\right]^{0.5} \\
& =0.53 \mathrm{~g} / 100 \mathrm{~g} \text { RJ. }
\end{aligned}
$$

Thus the expanded uncertainty of $\mathrm{W}_{\mathrm{Wed}}$ at a 95\% level of confidence is (considering 25 degrees of freedom for the standard uncertainty):

$$
\begin{aligned}
\mathrm{U}_{95 \%}\left(\mathrm{~W}_{\text {Wed }}\right) & =\mathrm{k}_{(95 \%, v=25)} \cdot \mathrm{u}\left(\mathrm{W}_{\text {Wed }}\right) \\
& =1.09 \mathrm{~g} / 100 \mathrm{~g} \text { RJ. }
\end{aligned}
$$

Table III reports the water values, according to Wedmore's formula, in function of the measured RI, in the range 50-70\% for the water content.

\section{DISCUSSION}

The reading of the refractive index for $\mathrm{RJ}$ is not so easy as it may be for honey, because of a blurred intersection between the dark and bright zones in the refractometer screen. However, the repeatability of the RI measure proved to be satisfactory $\left(\mathrm{U}_{r, 95 \%}(\mathrm{RI})\right.$ $=0.0003$ RIU) and therefore suitable for assessing whether RI values could be usefully correlated to the RJ water content. With its low repeatability uncertainty $(0.28 \mathrm{~g} / 100 \mathrm{~g} \mathrm{RJ}$ at $95 \%$ confidence level) the VO method proved to be a reliable reference for evaluating the fitness of the RI measure used to estimate the water content of RJ. When an oven temperature of $60{ }^{\circ} \mathrm{C}$ is used, even with the application of vacuum, a certain degree of browning, due to the Maillard reaction, is reported to occur (Garcia-Amoedo and Almeida-Muradian, 2002). The $48{ }^{\circ} \mathrm{C}$ temperature used in this study proved to be more conservative for the sample, as it left the colour of the sample unchanged, and also proved to be sufficient for drying as it avoided the formation of a superficial brown sugar crust that prevents complete evaporation.

In the work of Braines and Gamov (1962), 45 experimental points (VO water content result vs. RI measure) were presented. Performing a basic statistical analysis of these data, the experimental points result very strongly correlated $\left(\mathrm{R}^{2}=0.9997\right)$ by a linear fit with a slope not very dissimilar (roughly 110\%) from the one found in this work: $\mathrm{W}_{\mathrm{RI}}(\%)=-540.7 \times$ $\mathrm{RI}+816.7$. However, the intercept value of the fit on Braines and Gamov's data is higher than in our equation (a) which is reflected in the higher values $(3.2 \%-3.9 \%)$ in their work compared to the present study. This difference may be due to some differences in oven drying conditions, probably higher temperature. 
Table III. RJ water content values ( $\%=\mathrm{g} / 100 \mathrm{~g}$ RJ, fresh weight) in function of the .measured $\mathrm{RI}$ at $20{ }^{\circ} \mathrm{C}$ according to Wedmore's formula.

\begin{tabular}{|c|c|c|c|c|c|c|c|c|c|}
\hline R.I. & water\% & R.I. & water\% & R.I. & water\% & R.I. & water\% & R.I. & water\% \\
\hline 1.4166 & $50.0 \%$ & 1.4084 & $53.9 \%$ & 1.4002 & $57.8 \%$ & 1.3920 & $61.8 \%$ & 1.3838 & $65.9 \%$ \\
\hline 1.4164 & $50.1 \%$ & 1.4082 & $54.0 \%$ & 1.4000 & $57.9 \%$ & 1.3918 & $61.9 \%$ & 1.3836 & $66.0 \%$ \\
\hline 1.4162 & $50.2 \%$ & 1.4080 & $54.1 \%$ & 1.3998 & $58.0 \%$ & 1.3916 & $62.0 \%$ & 1.3834 & $66.1 \%$ \\
\hline 1.4160 & $50.3 \%$ & 1.4078 & $54.1 \%$ & 1.3996 & $58.1 \%$ & 1.3914 & $62.1 \%$ & 1.3832 & $66.2 \%$ \\
\hline 1.4158 & $50.4 \%$ & 1.4076 & $54.2 \%$ & 1.3994 & $58.2 \%$ & 1.3912 & $62.2 \%$ & 1.3830 & $66.3 \%$ \\
\hline 1.4156 & $50.5 \%$ & 1.4074 & $54.3 \%$ & 1.3992 & $58.3 \%$ & 1.3910 & $62.3 \%$ & 1.3828 & $66.4 \%$ \\
\hline 1.4154 & $50.6 \%$ & 1.4072 & $54.4 \%$ & 1.3990 & $58.4 \%$ & 1.3908 & $62.4 \%$ & 1.3826 & $66.5 \%$ \\
\hline 1.4152 & $50.7 \%$ & 1.4070 & $54.5 \%$ & 1.3988 & $58.5 \%$ & 1.3906 & $62.5 \%$ & 1.3824 & $66.6 \%$ \\
\hline 1.4150 & $50.8 \%$ & 1.4068 & $54.6 \%$ & 1.3986 & $58.6 \%$ & 1.3904 & $62.6 \%$ & 1.3822 & $66.7 \%$ \\
\hline 1.4148 & $50.9 \%$ & 1.4066 & $54.7 \%$ & 1.3984 & $58.7 \%$ & 1.3902 & $62.7 \%$ & 1.3820 & $66.8 \%$ \\
\hline 1.4146 & $50.9 \%$ & 1.4064 & $54.8 \%$ & 1.3982 & $58.8 \%$ & 1.3900 & $62.8 \%$ & 1.3818 & $66.9 \%$ \\
\hline 1.4144 & $51.0 \%$ & 1.4062 & $54.9 \%$ & 1.3980 & $58.9 \%$ & 1.3898 & $62.9 \%$ & 1.3816 & $67.0 \%$ \\
\hline 1.4142 & $51.1 \%$ & 1.4060 & $55.0 \%$ & 1.3978 & $59.0 \%$ & 1.3896 & $63.0 \%$ & 1.3814 & $67.1 \%$ \\
\hline 1.4140 & $51.2 \%$ & 1.4058 & $55.1 \%$ & 1.3976 & $59.1 \%$ & 1.3894 & $63.1 \%$ & 1.3812 & $67.2 \%$ \\
\hline 1.4138 & $51.3 \%$ & 1.4056 & $55.2 \%$ & 1.3974 & $59.1 \%$ & 1.3892 & $63.2 \%$ & 1.3810 & $67.3 \%$ \\
\hline 1.4136 & $51.4 \%$ & 1.4054 & $55.3 \%$ & 1.3972 & $59.2 \%$ & 1.3890 & $63.3 \%$ & 1.3808 & $67.4 \%$ \\
\hline 1.4134 & $51.5 \%$ & 1.4052 & $55.4 \%$ & 1.3970 & $59.3 \%$ & 1.3888 & $63.4 \%$ & 1.3806 & $67.5 \%$ \\
\hline 1.4132 & $51.6 \%$ & 1.4050 & $55.5 \%$ & 1.3968 & $59.4 \%$ & 1.3886 & $63.5 \%$ & 1.3804 & $67.6 \%$ \\
\hline 1.4130 & $51.7 \%$ & 1.4048 & $55.6 \%$ & 1.3966 & $59.5 \%$ & 1.3884 & $63.6 \%$ & 1.3802 & $67.7 \%$ \\
\hline 1.4128 & $51.8 \%$ & 1.4046 & $55.7 \%$ & 1.3964 & $59.6 \%$ & 1.3882 & $63.7 \%$ & 1.3800 & $67.8 \%$ \\
\hline 1.4126 & $51.9 \%$ & 1.4044 & $55.8 \%$ & 1.3962 & $59.7 \%$ & 1.3880 & $63.8 \%$ & 1.3798 & $67.9 \%$ \\
\hline 1.4124 & $52.0 \%$ & 1.4042 & $55.9 \%$ & 1.3960 & $59.8 \%$ & 1.3878 & $63.9 \%$ & 1.3796 & $68.0 \%$ \\
\hline 1.4122 & $52.1 \%$ & 1.4040 & $56.0 \%$ & 1.3958 & $59.9 \%$ & 1.3876 & $64.0 \%$ & 1.3794 & $68.1 \%$ \\
\hline 1.4120 & $52.2 \%$ & 1.4038 & $56.1 \%$ & 1.3956 & $60.0 \%$ & 1.3874 & $64.1 \%$ & 1.3792 & $68.2 \%$ \\
\hline 1.4118 & $52.3 \%$ & 1.4036 & $56.2 \%$ & 1.3954 & $60.1 \%$ & 1.3872 & $64.2 \%$ & 1.3790 & $68.3 \%$ \\
\hline 1.4116 & $52.4 \%$ & 1.4034 & $56.2 \%$ & 1.3952 & $60.2 \%$ & 1.3870 & $64.3 \%$ & 1.3788 & $68.4 \%$ \\
\hline 1.4114 & $52.4 \%$ & 1.4032 & $56.3 \%$ & 1.3950 & $60.3 \%$ & 1.3868 & $64.4 \%$ & 1.3786 & $68.5 \%$ \\
\hline 1.4112 & $52.5 \%$ & 1.4030 & $56.4 \%$ & 1.3948 & $60.4 \%$ & 1.3866 & $64.5 \%$ & 1.3784 & $68.6 \%$ \\
\hline 1.4110 & $52.6 \%$ & 1.4028 & $56.5 \%$ & 1.3946 & $60.5 \%$ & 1.3864 & $64.6 \%$ & 1.3782 & $68.7 \%$ \\
\hline 1.4108 & $52.7 \%$ & 1.4026 & $56.6 \%$ & 1.3944 & $60.6 \%$ & 1.3862 & $64.7 \%$ & 1.3780 & $68.8 \%$ \\
\hline 1.4106 & $52.8 \%$ & 1.4024 & $56.7 \%$ & 1.3942 & $60.7 \%$ & 1.3860 & $64.8 \%$ & 1.3778 & $68.9 \%$ \\
\hline 1.4104 & $52.9 \%$ & 1.4022 & $56.8 \%$ & 1.3940 & $60.8 \%$ & 1.3858 & $64.9 \%$ & 1.3776 & $69.0 \%$ \\
\hline 1.4102 & $53.0 \%$ & 1.4020 & $56.9 \%$ & 1.3938 & $60.9 \%$ & 1.3856 & $65.0 \%$ & 1.3774 & $69.1 \%$ \\
\hline 1.4100 & $53.1 \%$ & 1.4018 & $57.0 \%$ & 1.3936 & $61.0 \%$ & 1.3854 & $65.1 \%$ & 1.3772 & $69.3 \%$ \\
\hline 1.4098 & $53.2 \%$ & 1.4016 & $57.1 \%$ & 1.3934 & $61.1 \%$ & 1.3852 & $65.2 \%$ & 1.3770 & $69.4 \%$ \\
\hline 1.4096 & $53.3 \%$ & 1.4014 & $57.2 \%$ & 1.3932 & $61.2 \%$ & 1.3850 & $65.3 \%$ & 1.3768 & $69.5 \%$ \\
\hline 1.4094 & $53.4 \%$ & 1.4012 & $57.3 \%$ & 1.3930 & $61.3 \%$ & 1.3848 & $65.4 \%$ & 1.3766 & $69.6 \%$ \\
\hline 1.4092 & $53.5 \%$ & 1.4010 & $57.4 \%$ & 1.3928 & $61.4 \%$ & 1.3846 & $65.5 \%$ & 1.3764 & $69.7 \%$ \\
\hline 1.4090 & $53.6 \%$ & 1.4008 & $57.5 \%$ & 1.3926 & $61.5 \%$ & 1.3844 & $65.6 \%$ & 1.3762 & $69.8 \%$ \\
\hline 1.4088 & $53.7 \%$ & 1.4006 & $57.6 \%$ & 1.3924 & $61.6 \%$ & 1.3842 & $65.7 \%$ & 1.3760 & $69.9 \%$ \\
\hline 1.4086 & $53.8 \%$ & 1.4004 & $57.7 \%$ & 1.3922 & $61.7 \%$ & 1.3840 & $65.8 \%$ & 1.3758 & $70.0 \%$ \\
\hline
\end{tabular}

The good correlation between the water content of royal jelly $\left(\mathrm{R}^{2}=0.9605\right)$ determined by vacuum oven and the refraction index measures allows to conclude that the refractometric evaluation of water content, already used for honey, may be employed for RJ. The linear relationship (a) we found provides water content values extremely similar to those obtained from the Wedmore equation $\left(\mathrm{R}^{2}=0.9999\right)$, that can therefore be reliably applied to $\mathrm{RJ}$ with a suitable level of uncertainty $\left(\mathrm{U}_{95 \%}\left(\mathrm{~W}_{\mathrm{Wed}}\right)=1.09 \%\right)$.

The refractometric measurement is a valid method for the evaluation of RJ water content, 
much simpler and faster than the gravimetric and Karl Fischer determinations. It is reliable enough for a rapid quality control check of the product and requires only inexpensive instruments. It is suggested that this new validated method become the standard method for determining the water content in RJ. In a next step the dependence of the refractometric measurement on the temperature should be established, as it is the case with the honey humidity refractometric determination.

\section{ACKNOWLEDGEMENTS}

This research is part of the project BIOGEL, financed by the Ministero delle Politiche Agricole e Forestali.

\section{Détermination par réfractométrie de la teneur en eau de la gelée royale.}

\section{Gelée royale / réfractométrie / teneur en eau}

\section{Zusammenfassung - Refraktometrische Bestim-} mung des Wassergehaltes in Gelée Royale. Da Wasser den Hauptbestandteil von frischem Gelée Royale (GR) darstellt, ist die Bestimmung des Wasseranteils ein wichtiger Aspekt der Qualitätskontrolle dieses Produktes. Bislang wurden Gefriertrocknung, Trocknung in einem Ofen oder einem Vakuumofen (VO), Infrarottrocknung und die Karl Fischer-Methode für diese Bestimmung genutzt. Diese Methoden sind zeitaufwändig oder benötigen besondere Ausrüstung. Ziel dieser Arbeit war herauszufinden, inwieweit die Bestimmung des einfachen refraktometrischen Index (RI), wie sie zur Bestimmung des Wassergehaltes im Honig bereits benutzt wird, eine für die Zwecke der Qualitätskontrolle ausreichend zuverlässige Methode darstellt. Zunächst wurde die Wiederholbarkeit der RI und der Wassergehaltsbestimmung mit der VO Methode abgeschätzt (Tab. I). Danach wurden 27 verschiedene Proben von GR durch eine 24stündige Vakuumtrocknung bei $48{ }^{\circ} \mathrm{C}$ auf ihren Wassergehalt untersucht, wobei wir fast den ganzen Bereich der in der Literatur gefundenen Werte erhielten. Der Refraktionsindex der gleichen Proben wurde anhand eines thermostatgeregelten Abbe Refraktometers bestimmt (Tab. II). Hierbei wurde eine einfache lineare Beziehung $\left(\mathrm{R}^{2}=0,96\right)$ zwischen dem Refraktionsindex und dem Wassergehalt gefunden (Abb. 1). Bei gleichzeitiger Anwendung dieser experimentell gefundenen Beziehung und Wedmore's Gleichung für RI Messungen waren die erhaltenen Wassergehaltswerte außerordentlich ähnlich $\left(\mathrm{R}^{2}=0,9999\right)$. Tabelle III gibt die anhand der Wedgemore Formel ermittelten Werte des Wassergehaltes bei Verwendung von RI ab GR bei $20^{\circ} \mathrm{C}$ an. Wir schließen daraus, dass die Gleichung von Wedgemore auch in GR für die Bestimmung des Wassergehaltes anwendbar ist. Durch Anwendung dieser Gleichung auf die RI Messungen wird ein für die Zwecke der Qualitätskontrolle ausreichender Ungenauigkeitsbereich für die Abschätzung des Wassergehaltes in GR erzielt $\left(\mathrm{U}_{0.95}\left(\mathrm{~W}_{\text {Wed }}\right)=\right.$ $1,1 \%)$. Daher erwies sich die refraktometrische Bestimmung auch für die Bestimmung des Wassergehaltes in GR als gültig und stellt damit eine weitaus einfachere und schnellere Methode dar als die bisher verwendeten Verfahren.

\section{Gelée Royale / Wasser / Refraktometer}

\section{REFERENCES}

Bloodworth B.C., Harn C.S., Hock C.T., Boon Y.O. (1995) J. AOAC Int. 78, 1019-1023.

Bogdanov S., Martin P., Lüllmann C. (1997) Harmonised methods of the European Honey Commission. Determination of moisture, refractometric method, Apidologie Extra issue, 11-13.

Braines L., Gamov L. (1962) Fast method for the determination of the water content of royal jelly, Information Bull. Ryasan Sci. Apic. Inst., Ryasan, 27-31 [in Russian]

Garcia-Amoedo L.H., de Almeida-Muradian L.B. (2002) Comparação de metodologias para a determinação de umidade em geléia real, Quim. Nova 25, 676-679.

EURACHEM/CITAC (2000) Guide CG 4, Quantifying Uncertainty in Analytical Measurement, 2nd ed.

International Honey Commission (IHC) (2004) Minutes of the meeting in Udine (Italy), [online] http://www.alp.admin.ch/themen/00502/ $00555 / 00561 /$ index.html ?lang $=\mathrm{fr}$ (accessed on 9 October 2007).

ISO V.I.M. (1993) International Vocabulary of Basic and General Terms in Metrology, 2nd ed., International Organization for Standardization, Geneva, Switzerland.

Lercker G., Caboni M.F., Vecchi M.A., Sabatini A.G., Nanetti A. (1992) Caratterizzazione dei principali costituenti della gelatina reale, Apicoltura 8, 27-37.

Palma M.S. (1992) Composition of freshly harvested Brazilian Royal Jelly: Identification of carbohydrates from the sugar fraction, J. Apic. Res. 31, 42-44. 
Piana L. (1996) Royal jelly, In Krell R., Value added products from beekeeping, FAO Agric. Serv. Bull. 124, 195-226.

Pourtallier J., Davico R., Rognone M.C. (1990) Les analyses dans le contrôle de pureté de la gelée royale, L'Abeille de France 753, 405-407.

Sesta G. (2006) Determination of sugars in royal jelly by HPLC, Apidologie 37, 84-90.

Serra Bonvehi J. (1991) Study of adulteration of royal jelly with other honey bee products and water, Prod. Sanidad Anim. 6, 99-111.
Serra Bonvehi J. (1992) Azucares, acidez y pH de la jalea real, Anal. Bromatol. 44, 65-69.

Shkenderov S., Ivanov T. (1983) Bee Products, Zemizdat, Sofia [in Bulgarian].

UNI CEI ENV 13005 (2000) Guide to the expression of uncertainty in measurement, Ente Italiano di Unificazione, Milano, Italy, 2000.

Wedmore E. (1955) The accurate determination of the water content of honeys, Bee World 36, 197-206. 